\title{
Simulation of variations in the composition of samples in the evaluation of neutral detergent fiber contents by using cellulose standard in filter bags made from different textiles ${ }^{1}$
}

\author{
Tiago Neves Pereira Valente ${ }^{2}$, Edenio Detmann ${ }^{3}$, Sebastião de Campos Valadares Filho ${ }^{3}$, \\ Mário Fonseca Paulino ${ }^{3}$, Janderson Florêncio Figueiras ${ }^{2}$, Marjorrie Augusto de Souza ${ }^{2}$ \\ ${ }^{1}$ Trabalho financiado pelo CNPq, FAPEMIG (PPM) e INCT - Ciência Animal. \\ 2 Programa de Pós-Graduação em Zootecnia, Universidade Federal de Viçosa, Viçosa-MG. Bolsista do CNPq. \\ ${ }^{3}$ Departamento de Zootecnia, UFV, Viçosa-MG. Pesquisador do CNPq e do INCT - Ciência Animal.
}

\begin{abstract}
The objective of this study was to evaluate the efficiency of using nylon textiles (50 $\mu \mathrm{m}$ ), F57 (Ankom ${ }^{\circledR}$ ) and non-woven textile (NWT $-100 \mathrm{~g} / \mathrm{m}^{2}$ ) on laboratory evaluation of neutral detergent fiber (NDF) by using quantitative filter paper as purified cellulose standard and by simulating different composition of samples with additions of corn starch, pectin, casein and soybean oil. The quantitative filter paper was processed in a knife mill with a 1-mm screen sieve and the procedures for analyses of NDF contents were performed in a fiber analyzer (Ankom220 ${ }^{\circledR}$ ). Four experiments were carried out with additions of different ingredients into the filter paper: corn starch added at the levels of 15 or $50 \%$; pectin, 15 or $50 \%$; casein, 10 or $30 \%$; and soybean oil at $0,5,10,15,25$ or $50 \%$ of dry matter, respectively. The ratio $20 \mathrm{mg}$ of dry matter $/ \mathrm{cm}^{2}$ of surface was followed. When it was relevant, in function of the evaluated treatments, heat-stable $\alpha$-amylase was used. The use of F57 and NWT resulted in accurate estimates of NDF contents whereas nylon textile caused loss of insoluble fibrous particles, compromising accuracy of the results. For samples containing starch, use of heat-stable $\alpha$-amylase is recommended in the evaluation of NDF contents. Pectin and casein are completely solubilized by neutral detergent solution. Levels of oil higher than $10 \%$ cause overestimation of NDF contents.
\end{abstract}

Key Words: F57, heat-stable $\alpha$-amylase, nylon, woven-non textile

\section{Introduction}

The development of Ankom ${ }^{\circledR}$ filter bag system for fiber analyses creates new perspectives for textiles utilization in laboratorial feed evaluation. Filter bag system was found as advantageous compared to conventional system which used crucibles due to its lower labor and cost (Cherney, 2000).

In this context, several textiles have been suggested for fiber analysis, such as nylon, F57 (Ankom ${ }^{\circledR}$ ) and nonwoven textile (NWT, $100 \mathrm{~g} / \mathrm{m}^{2}$ ). However, one of the main constraints to textile utilization for analysis of fibrous residues, as neutral detergent fiber (NDF), is associated with the probability of insoluble particles loss through textile mesh (Vanzant et al., 1998; Hvelpund \& Weisbjerg, 2000; Casali et al., 2009; Valente et al., 2011a). Such losses can produce inaccurate results.

Actually, fiber contents estimates are normally evaluated only for precision because the chemical heterogeneity of NDF hampers the establishment of analytical standard which could assist the evaluation of accuracy of estimates (Casali et al., 2009). Quantitative filter papers are produced from purified cellulose, a natural component of NDF. Thereby, by analogy, such material is composed only by NDF and it was proposed as analytical standard to check the accuracy of insoluble fiber analyses (Valente et al., 2011a). However, when textiles are used in fiber analysis, it is possible to occur interactions with different compounds of samples and retention of non-fibrous components which should be solubilized. In both cases, NDF content would be overestimated.

Thus, the objective of this work was to evaluate the efficiency of nylon, F57 and NWT textiles in NDF analysis by using quantitative filter paper as cellulose standard and simulating different sample compositions with the addition of starch, pectin, casein, and soybean oil.

\section{Material and Methods}

Four experiments were carried out in Laboratório de Nutrição Animal in the Departamento de Zootecnia at the Universidade Federal de Viçosa, Viçosa, Minas Gerais.

In all experiments, $4 \times 5 \mathrm{~cm}$ bags were manufactured with nylon (50 $\mu \mathrm{m}$ of porosity) and NWT $\left(100 \mathrm{~g} / \mathrm{m}^{2}\right)$. The F57 
bags were bought directly from the manufacturer $\left(\right.$ Ankom ${ }^{\circledR}$ ). The samples were put in the bags following the ratio of $20 \mathrm{mg}$ dry matter (DM)/ $\mathrm{cm}^{2}$ of surface (Nocek, 1988). For all experimental procedures, the bags were heat-sealed after putting the samples.

The NDF analysis procedures were performed in a fiber analyzer (Ankom ${ }^{220}{ }^{\circledR}$ ) using the neutral detergent formulation suggested by Mertens (2002), without sodium sulfite. The detergent/sample ratio was kept always at $100 \mathrm{~mL} / \mathrm{g}$ DM. There was no procedure for protein or ash correction in NDF analysis.

The heat-stable $\alpha$-amylase (Termamyl 2X, Novozymes) was used according to demands by the treatments. For adequate enzyme activation, the neutral detergent was added over samples at room temperature, then heat-stable $\alpha$-amylase was added. After that, the detergent was heated and the extraction time (1 hour) was counted from the moment when extraction temperature was reached $\left(100^{\circ} \mathrm{C}\right)$.

After neutral detergent extraction, the bags were washed sequentially with hot distilled water and acetone, ovendried $\left(60^{\circ} \mathrm{C} / 72\right.$ hours following $105^{\circ} \mathrm{C} / 45$ minutes), put in a dissecator and then weighed. The weighing procedure was done by limiting to 20 the number of bags put in the dissecator. Such restriction was adopted to avoid constraints due to moisture absorption by the residue (Sampaio et al., 2011).

Before extraction procedures, all bags were cleaned with boiling neutral detergent, hot distilled water and acetone, oven-dried and weighed to obtain the blank weights as described before.

The analytical standard of NDF was obtained from quantitative filter paper (fast filter speed; $12.5 \mathrm{~cm} \varnothing$; ashless; code 050154 ; Vetec ${ }^{\circledR}$ ). This material is formed by purified cellulose and presents $0.0086 \%$ of ash and $96.53 \%$ of DM. The paper was processed in a knife mill to pass through 1-mm screen sieve as recommended by Valente et al. (2011a).

Considering that quantitative filter paper is a purified compound, it was assumed that it can be used as standard to check the accuracy of estimates of NDF contents (Valente et al., 2011a). Such assumption must be highlighted because common samples, such as forages or concentrates, can be used to evaluate the precision of estimates only, not accuracy (Van Soest, 1994; Casali et al., 2009).

In the first experiment, it was simulated samples containing different levels of starch. In this way, besides cellulose standard, corn starch (Sigma S-5296, 91.62\% DM) was put in the bags at the levels of 15 or $50 \%$ of DM. It was also evaluated the utilization of heat-stable $\alpha$-amylase. Ten bags of each textile were used for each starch level, totalizing 60 bags ( 30 with and 30 without heat-stable $\alpha$-amylase).
The experiment was carried out according to a completely random design using a $3 \times 2 \times 2$ factorial arrangement (three textiles, two levels of starch, and using or not heat-stable $\alpha$-amylase).

In the second experiment, samples containing different levels of pectin were simulated. Thereby, besides cellulose standard, pectin (pectin from citrus fruits, Sigma P-9135, $87.55 \%$ DM) was put in the bags at the levels of 15 or $50 \%$ of DM. Five bags of each textile were used for each pectin level, totalizing 30 bags.

The experiment was carried out according to a completely random design using a $3 \times 2$ factorial arrangement (three textiles and two levels of pectin).

In the third experiment, samples were simulated to contain 20\% of starch (corn starch, Sigma S-5296, 91.62\% DM) and 10 or $30 \%$ of soluble protein (casein from bovine milk technical grade, Sigma C-7078, 91.65\% DM). In this experiment, the utilization of heat-stable $\alpha$-amylase was also evaluated. Ten bags of each textile were used for each casein level, totalizing 60 bags (30 with and 30 without heat-stable $\alpha$-amylase).

The experiment was carried out according to a completely random design using a $3 \times 2 \times 2$ factorial arrangement (three textiles, two levels of casein, and using or not heat-stable $\alpha$-amylase).

The fourth experiment was performed to evaluate samples containing different levels of ether extract (EE). Thus, samples were simulated by adding $0,5,10,15,25$ or $50 \%$ of soybean oil on cellulose standard, as DM basis. The oil had no protein, ash or carbohydrates and presented $100 \%$ DM. Five bags of each textile were used for each oil level, totalizing 90 bags.

The experiment was carried out according to a completely random design using a $3 \times 6$ factorial arrangement (three textiles and six oil levels).

In all experiments it was evaluated the recovery bias of NDF, which was estimated as:

$$
N R F=\frac{M o-M e}{M e} \times 100
$$

in which, $\mathrm{NRF}=\mathrm{NDF}$ recovery bias (\%), $\mathrm{Me}=$ the expected mass of NDF or mass of cellulose standard (g), and Mo $=$ the observed mass of NDF or the residue obtained after analysis (g).

The bias estimates were obtained as described above based on assumption that cellulose standard presents $100 \%$ of NDF, as DM basis (Valente et al., 2011a). From this, considering that other components used in the experiments were not components of NDF, any difference of residue in the bags from added standard mass must be assumed as 
bias. In this context, negative bias means loss of insoluble fiber and positive bias means retention of non-NDF compounds.

Confidence intervals $(1-\alpha=0.99)$ were estimated for all average biases. When the parametric value 0 (zero) were found within the confidence interval, it was assumed that recovery bias is not significant $(\mathrm{P}>0.01)$.

Moreover, the average biases were compared among the levels of each evaluated factor by using Tukey-Kramer test, except in comparisons among levels of oil in the fourth experiment, which was performed by using non-linear regression.

All statistical procedures were performed by using SAS (PROC GLM and PROC NLIN). It was adopted 0.01 as critical limit for type I error.

\section{Results and Discussion}

In the first experiment, it was observed a triple interaction effect $(\mathrm{P}<0.01)$. When heat-stable $\alpha$-amylase was not used, the NDF contents were overestimated $(\mathrm{P}<0.01)$ and presented similar biases for both starch levels (Table 1). The biases varied from +3.89 to $+9.88 \%$. Such pattern corroborates the interference of starch on laboratorial evaluation of NDF.

When heat-stable $\alpha$-amylase was not used, significant bias was observed for all types of filter bags $(\mathrm{P}<0.01)$. However, the biases were generally lower for nylon than for F57 and NWT $(\mathrm{P}<0.01)$. Such behavior was more evident when $50 \%$ of starch was considered (Table 1 ).

On the other hand, the biases for both starch levels were not significant $(\mathrm{P}>0.01)$ when $\alpha$-amylase was used, which brings into evidence the removal of contaminant starch from insoluble residue (Table 1). However, negative average bias (considering both starch levels) were verified for nylon $(\mathrm{P}<0.01)$.
By considering the utilization or not of heat-stable $\alpha$-amylase when nylon was used, it is evidenced that lower bias obtained without using $\alpha$-amylase does indicate loss of insoluble fibrous particles rather than a better efficiency of that textile. Such pattern would seem to indicate that lower starch contamination would be obtained with nylon, what is not supported when utilization of $\alpha$-amylase is considered (Table 1).

The loss of fibrous particles has been pointed out as the main constraint for using nylon in laboratorial evaluations of NDF (Casali et al., 2009; Valente et al., 2011a; 2011b). Such restriction was not observed with NWT and F57, which presented similar accuracy (Table 1).

Generally, the recovery biases of NDF with regard to utilization of heat-stable $\alpha$-amylase endorse that starch can overestimate NDF contents if $\alpha$-amylase is not used (Table 1). Similar results were reported by Cherney et al. (1989), who evaluated NDF contents in forages containing grains.

In this work, the utilization of heat-stable $\alpha$-amylase caused an efficient removal of starch when it was added on neutral detergent at room temperature. So, it can be stated that there is not limitations concerning enzymatic action, which counter some previous reports, in which less efficient amylases may have been used and at least one night was recommended for adequate action of enzyme on samples (McQueen \& Nicholson, 1979) and sometimes using urea solution (Van Soest et al., 1991) before neutral detergent extraction. In another report, the utilization of $\alpha$-amylase demanded two analytical steps (Undersander et al., 1993). Thereby, the results of this work indicate that the analytical procedures can be performed with greater convenience.

The positive biases of NDF are explained by the fact that starch can gelatinize when exposed to temperatures of 90 to $100^{\circ} \mathrm{C}$ (Hall, 2007), which hampers its removal during

Table 1 - Recovery bias (\%) of neutral detergent fiber with inclusion of 15 or $50 \%$ of starch and utilization of heat-stable $\alpha$-amilase using F57, NWT or nylon filter bags

\begin{tabular}{|c|c|c|c|c|c|}
\hline \multirow[b]{2}{*}{$\alpha$-amilase } & \multirow[b]{2}{*}{ Starch (\%) } & \multicolumn{3}{|c|}{ Filter bags ${ }^{1,2}$} & \multirow[b]{2}{*}{ Mean } \\
\hline & & F57 & NWT & Nylon & \\
\hline \multirow{3}{*}{ without } & 15 & $5.41 * \mathrm{Ba}$ & $8.97^{*} \mathrm{Aa}$ & $6.33^{*} \mathrm{Aa}$ & $6.90 * \mathrm{~A}$ \\
\hline & 50 & $9.88 * \mathrm{Aa}$ & $6.98 * \mathrm{Aa}$ & $3.89 * \mathrm{Ab}$ & $6.91 * \mathrm{~A}$ \\
\hline & mean & $7.65 * a$ & $7.97 * a$ & $5.11 * b$ & - \\
\hline \multirow{3}{*}{ with } & 15 & $-0.20 \mathrm{Aa}$ & $-0.39 \mathrm{Aa}$ & $-1.73 * \mathrm{Aa}$ & $-0.77 \mathrm{~A}$ \\
\hline & 50 & $-0.51 \mathrm{Aa}$ & $-0.52 \mathrm{Aa}$ & $-1.25 \mathrm{Aa}$ & $-0.76 \mathrm{~A}$ \\
\hline & mean & $-0.36 a$ & $-0.46 a$ & $-1.49 * \mathrm{a}$ & $\mathrm{CV}(\%)=45.9$ \\
\hline
\end{tabular}

${ }^{1}$ Means within the same row followed by different lower case letters, or in the same column followed by different capital letters, are different according to Tukey-Kramer test $(\mathrm{P}<0.01)$.

$2(*)$ The bias differs from zero $(\mathrm{P}<0.01)$. 
filtration. When heat-stable $\alpha$-amylase was used, starch was removed from all types of filter bags. This pattern is in agreement with recommendations of Association of Official Analytical Chemists for starch containing samples (Mertens, 2002) and avoids overestimation of NDF content (Faithfull, 2002).

It was not observed effects of pectin levels or interaction of pectin levels and textiles on recovery bias of NDF $(\mathrm{P}>0.01)$ in the second experiment. With regard to textiles, similar results were produced by NWT and F57 $(\mathrm{P}>0.01)$; however, they both differ from nylon $(\mathrm{P}<0.01)$. On the other hand, negative recovery biases were observed for nylon $(\mathrm{P}<0.01)$. This result emphasizes once more that nylon can propitiate significant loss of insoluble fibrous particles (Table 2).

Pectin, despite being a cell wall component (Hall, 2003), is completely solubilized by neutral detergent and it is supposed to be a soluble fibrous compound (Bailey \& Ulyatt, 1970; Dryden, 2008). There are some evidences indicating that pectin can be solibilized only by hot water, which would demand temperatures higher than $80^{\circ} \mathrm{C}$ for its complete extraction (Van Soest, 1994). The soluble fiber presents ruminal degradation that is different from the others compounds of insoluble fiber (Van Soest, 1967; Hall et al., 1997; Russell, 2002) and its incomplete extraction by neutral detergent could confound the results obtained through laboratorial evaluations and digestibility assays (Chesson \& Monro, 1982).

According to Undersander et al. (1993), samples containing high pectin levels could present some problems during filtration, particularly if there is contact with cold or not heated crucibles. However, according the results here presented, in spite of using $50 \%$ of pectin in sample, it was not observed positive bias (Table 2), which indicates that there were no problems concerning retention of pectin residues during filtration. This seems to be an advantage of using filter bags because they are heated together with samples and the problem described above is not possible to occur.

In the third experiment, interaction effect of textile and utilization of heat-stable $\alpha$-amylase was verified $(\mathrm{P}<0.01)$. The effect of different protein levels was not significant $(\mathrm{P}>0.01)$.

That experiment was proposed to simulate samples with more heterogeneous composition compared to those ones used in the first and second experiments and to provide samples with high cell content protein, which was represented by casein.

The protein has been pointed out as the major contaminant in the evaluation of insoluble fibrous residues
(Goering \& Van Soest, 1970). The most contaminant protein is represented by protein associated with fibrous compounds of the cell wall (Krishnamoorthy et al., 1982; Henriques et al., 2007); however, excess of protein in the sample, mainly glicoproteins, can hamper the filtration and overestimate NDF content (Undersander et al., 1993), as it was previously discussed for high pectin samples. Sometimes, some materials with high protein content demand using proteases to minimize interferences in NDF analysis (Van Soest \& Robertson, 1985). In this context, as discussed before, utilization of filter bags seems to be advantageous in the evaluation of such samples.

The evaluation of interaction of textiles and $\alpha$-amylase in the third experiment (Table 3) corroborates the results of first experiment (Table 1 ). When $\alpha$-amylase was not used, there was a positive recovery biases for all textiles $(\mathrm{P}<0.01)$; however, the bias were lower $(\mathrm{P}<0.01)$ for nylon compared to NWT and F57, which did not differ from each other ( $\mathrm{P}>0.01$ ). Considering the utilization of $\alpha$-amylase, NWT and F57 did not present significant recovery bias $(\mathrm{P}>0.01)$. Nevertheless, negative bias was observed for nylon $(\mathrm{P}<0.01)$. Such pattern reiterates the losses of fibrous particles propitiate by nylon, which seems to be the cause of lower bias of nylon when $\alpha$-amylase was used (Table 3 ).

In the fourth experiment, there is interaction of textiles and oil levels on NDF recovery bias $(\mathrm{P}<0.01)$ (Table 4; Figures 1, 2 and 3).

Table 2 - Recovery bias (\%) of neutral detergent fiber with inclusion of 15 or $50 \%$ of pectin using F57, NWT or nylon filter bags

\begin{tabular}{llllc}
\hline & \multicolumn{3}{c}{ Filter bags } & \multirow{2}{*}{ Mean } \\
\cline { 2 - 4 } Pectin (\%) & F57 & NW T & Nylon & M \\
\hline 15 & -0.26 & -0.35 & $-2.42 *$ & -1.01 \\
50 & -0.44 & -0.40 & $-2.12 *$ & -0.99 \\
Mean $^{1,2}$ & $-0.35 b$ & $-0.37 b$ & $-2.27 * a$ & CV $(\%)=57.6$ \\
\hline
\end{tabular}

${ }_{1}^{1}$ Means within the row followed by different letters are different according to Tukey-Kramer test $(\mathrm{P}<0.01)$

${ }^{2}(*)$ The bias differs from zero $(\mathrm{P}<0.01)$.

Table 3 - Recovery bias (\%) of neutral detergent fiber according to utilization of heat-stable $\alpha$-amilase using F57, NWT or nylon filter bags

\begin{tabular}{|c|c|c|c|}
\hline \multirow[b]{2}{*}{$\alpha$-amilase } & \multicolumn{3}{|c|}{ Filter bag ${ }^{1,2}$} \\
\hline & F57 & T NT & Nylon \\
\hline with & $-0.45 \mathrm{Ba}$ & $-0.40 \mathrm{Ba}$ & $-1.20 * \mathrm{Ba}$ \\
\hline without & $5.44 * \mathrm{Aa}$ & $4.03 * \mathrm{Aa}$ & $1.04 * \mathrm{Ab}$ \\
\hline
\end{tabular}

R. Bras. Zootec., v.40, n.7, p.1596-1602, 2011 
Table 4 - Recovering bias (\%) of neutral detergent fiber according to different levels of soybean oil inclusion using F57, NWT and nylon filter bags

\begin{tabular}{lccc}
\hline & \multicolumn{3}{c}{ Filter bags bar, $^{1,2}$} \\
\cline { 2 - 4 } Soybean oil (\%) & F57 & N W T & Nylon \\
\hline 0 & $-0.40 \mathrm{a}$ & $-0.56 \mathrm{a}$ & $-1.06 \mathrm{a}$ \\
5 & $-0.40 \mathrm{a}$ & $-0.58 \mathrm{a}$ & $-1.28 \mathrm{a}$ \\
10 & $-0.15 \mathrm{a}$ & $-0.09 \mathrm{a}$ & $-1.24 \mathrm{a}$ \\
15 & $6.04 * \mathrm{a}$ & $5.45 * \mathrm{a}$ & $2.30 * \mathrm{~b}$ \\
25 & $23.24 * \mathrm{a}$ & $23.79 * \mathrm{a}$ & $17.80 * \mathrm{~b}$ \\
50 & $34.13 * \mathrm{~b}$ & $41.34 * \mathrm{a}$ & $29.60 * \mathrm{c}$ \\
\hline 1 Means within the row followed by different letters are different according to \\
Tukey-Kramer test $(\mathrm{P}<0.01)(\mathrm{CV}=19.6 \%)$. \\
$2(*)$ The bias differs from zero $(\mathrm{P}<0.01)$.
\end{tabular}

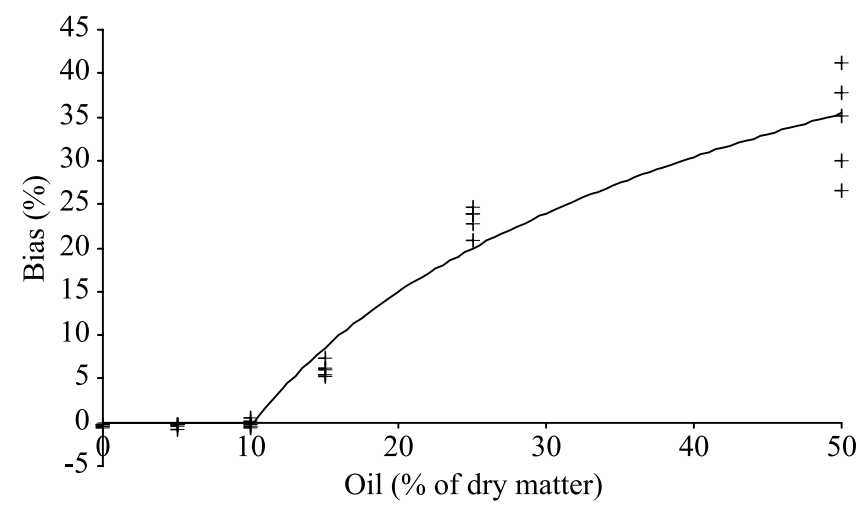

Figure 1 - Estimate of recovery bias of neutral detergent fiber as a function of soybean oil level in samples using F57 filter bags ( $\hat{Y}=0, \forall X<10.2526 ; \hat{Y}=-52.004+$ $\left.22.343 \ln (X), \forall X \geq 10.2526 ; \mathrm{R}^{2}=0.9360\right)$.

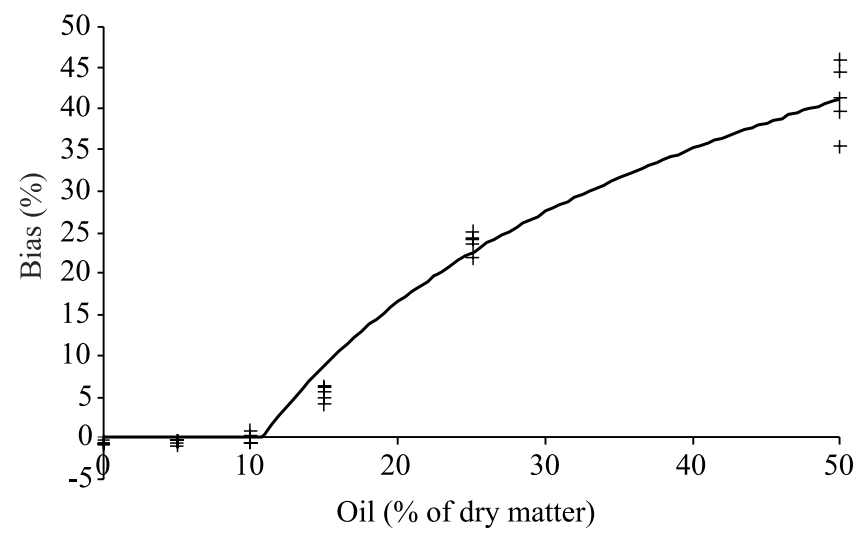

Figure 2 - Estimate of recovery bias of neutral detergent fiber as a function of soybean oil level in samples using NWT filter bags ( $\hat{Y}=0, \quad \forall X<10.8038 ; \hat{Y}=-63.993+$ 26.889ln(X), $\left.\forall X \geq 10.8038 ; \mathrm{R}^{2}=0.9698\right)$.

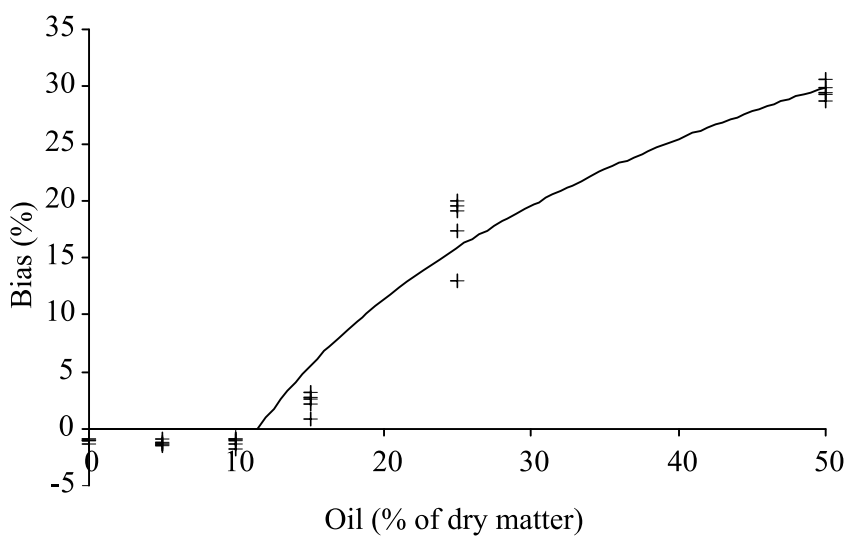

Figure 3 - Estimate of recovery bias of neutral detergent fiber as a function of soybean oil level in samples using nylon filter bags ( $\hat{Y}=0, \forall X<11.4598 \hat{Y}=-49.533+$ $\left.20.310 \ln (X), \forall X \geq 11.4598 ; \mathrm{R}^{2}=0.9611\right)$.

By evaluating different textiles nested to each oil level, it was observed that significant and positive recovery bias $(\mathrm{P}<0.01$ ) occur at 15,25 and $50 \%$ (Table 4 ). Generally, in these oil levels, lower biases were verified for nylon $(\mathrm{P}<0.01)$.

When nylon was used, the lower biases seem to be associated with two different causes. Firstly, as previously discussed and highlighted by other authors (Casali et al., 2009; Valente et al., 2011a; 2011b), the loss of fibrous particles due to mesh structure of nylon seems to constitute the major constraint for using it in laboratorial evaluation of insoluble fiber compounds. Such statement could be supported by results obtained at 0,5 , and $10 \%$ of oil. Even without significant effects of textiles $(\mathrm{P}>0.01)$, it was observed that nylon produced numerical recovery bias more prominent than ones observed with F57 and NWT (Table 4). This pattern could indicate that lower biases of nylon at high oil levels should be partially caused by loss of fibrous particles.

Although cellulose standard can be used to check the accuracy of NDF analysis, some limitations are still observed. The cellulose standard does not allow reproducing totally the high physical and chemical heterogeneity of whole feeds because it does not present cell content, and chemical linkages and physical interactions of cell wall compounds (Valente et al., 2011a). The fat of feeds is situated within the cell. So, its extraction would be dependent on the capacity of the detergent to remove it from inside the cell. In the simulation done in this study, oil was stirred together with the standard, which does not allow simulating completely the fat disposition observed inside the cell. When simulated sample is put in aqueous environment, formation of micelles 
could occur due to hydrophobicity of fat. According to studies in which scanner microscopy was used, the porosity of nylon mesh is higher than the ones observed in F57 and NWT (Casali et al., 2009; Valente et al., 2011b). Accordingly, when nylon is used, there would be a higher escape of whole micelles through mesh rather than a more efficient action of detergent. Such escape of micelles seems to be responsible for lower biases observed for nylon at high levels of oil (Table 4).

The evaluation of oil levels nested textiles suggested the adoption of a non-linear model with discontinuous structure. By using this model, it was possible to identify the oil level at which recovery became significant (Figures 1,2 and 3 ), which were $10.25,10.80$ and $11.45 \%$ of oil for F57, NWT and nylon, respectively. By disregarding the constraints of nylon utilization as previously presented, the information obtained with F57 and NWT brings into evidence that NDF recovery biases would be observed at oil levels higher than $10 \%$.

When oil levels are above $10 \%$, the overestimation of NDF contents can be explained based on the composition of neutral detergent. Sodium lauryl sulfate is a substance with detergent action and it is added to solution in a content sufficient enough to allow maximal solubilization of nonfibrous compounds using a minimal water volume (Van Soest, 1963). The molecule of this compound is a 12-carbon chain linked to a sulfate group. Such characteristic gives to sodium lauryl sulfate the anphipathic properties demanded for a detergent. This compound produces satisfactory results as detergent and can be found in several countries, which allow standardizing the neutral detergent solution (Van Soest \& Robertson, 1985).

Forages normally present low EE contents. However, when oil seeds are evaluated, saturation of neutral detergent solution can occur, which can make the lipid withdrawal incomplete. Such bias can be caused by partial solubilization of detergent in the apolar compounds (lipids), which will reduce its extraction capacity. Thereby, the partial degreasing of high-EE samples must be done (Van Soest et al., 1991; Faithfull, 2002).

In this context, by considering that results obtained by using different oil levels could represent the pattern of samples with different EE contents, partial degreasing is suggested for samples presenting EE content greater than $10 \%$. By doing that, the samples can be analyzed without significant bias from EE interference.

Generally, the results obtained in the four experiments have pointed out that utilization of nylon filter bags produces biased estimates of NDF contents. As previously reported, it has been showed that structure of nylon mesh presents wider porosity when compared to F57 and NWT. Additionally, nylon has been found more susceptible to rupture during analytical procedures (Casali et al., 2009; Valente et al., 2011b). Such characteristics do not allow recommending the nylon utilization for laboratory analyses of fibrous compounds.

Moreover, NWT and F57 present similar physical structures and, based on results of this work, they produce similar and accurate results. Thus, it can be inferred that NWT can be an alternative to F57, which presents higher cost. Such evidences corroborate the results obtained by other authors (Casali et al., 2009; Valente et al., 2011a).

\section{Conclusions}

The F57 (Ankom ${ }^{\circledR}$ ) and non-woven textile $\left(100 \mathrm{~g} / \mathrm{m}^{2}\right)$ filter bags produce accurate estimates of neutral detergent fiber. On the other hand, the accuracy of results obtained with nylon (50 ìm) filter bags is compromised by loss of particles. The utilization of heat-stable $\alpha$-amylase is recommended when starch containing samples are analyzed. Samples presenting ether extract content greater than $10 \%$ must be partially degreased before neutral detergent fiber analysis.

\section{References}

BAILEY, R.W.; ULYATT, M. Pasture quality and ruminant nutrition. II Carbohydrate and lignin composition of detergent-extracted residues from pasture grasses and legumes. New Zealand Journal of Agriculture Research, v.13, p.591-604, 1970.

CASALI, A.O.; DETMANN, E.; VALADARES FILHO, S.C. et al. Estimação de teores de componentes fibrosos em alimentos para ruminantes em sacos de diferentes tecidos. Revista Brasileira de Zootecnia, v.38, p.130-138, 2009.

CHERNEY, D.J.R. Characterization of forages by chemical analysis. In: GIVENS, D.I.; OWENS, E.; AXFORD, R.F.E. et al. (Eds.) Forage evaluation in ruminant nutrition. Wallingford: $\mathrm{CAB}$ International, 2000. p.281-300.

CHERNEY, D.J.R.; PATTERSON, J.A.; CHERNEY, J.H. Use of 2-ethoxyethanol and á-amilase in the neutral detergent fiber method of feed analysis. Journal of Dairy Science, v.72, p.3079-3084, 1989.

CHESSON, A.; MONRO, J.A. Legume pectin substances and their degradation in the ovine rumen. Journal of Science Food Agriculture, v.33, p.852-859, 1982.

DRYDEN, G.M. Animal nutrition science. Wallingford: CAB International, 2008. 320p.

FAITHFULL, N.T. Methods in agricultural chemical analysis. A Practical Handbook. Wallingford: CAB International, 2002. 266p.

GOERING, H.K.; Van SOEST, P.J. Forage fiber analyses (apparatus, reagents, procedures and some applications). Washington, D.C.: U. S. Government Printing Office, 1970. 20p. (USDA-ARS Agriculture Handbook, 379).

HALL, M.B. Challenges with nonfiber carbohydrate methods. Journal of Animal Science, v.81, p.3226-3232, 2003.

HALL, M.B. Methodological challenges in carbohydrate analyses. Revista Brasileira de Zootecnia, v.36, p.359-367, 2007 (supl. especial). 
HALL, M.B.; LEWIS, B.A.; Van SOEST, P.J. et al. A simple method for estimation of neutral detergent-soluble fibre. Journal of Science and Food Agriculture. v.74, p.441-449, 1997.

HENRIQUES, L.T.; DETMANN, E.; QUEIROZ, A.C. et al. Frações dos compostos nitrogenados associados à parede celular em forragens tropicais. Arquivo Brasileiro de Medicina Veterinária e Zootecnia, v.59, p.258-263, 2007.

HVELPLUND, T.; WEISBJERG, M.R. In situ techniques for the estimation of protein degradability and postrumen availability. In: GIVENS, D.I.; OWENS, E.; AXFORD, R.F.E. et al. (Eds.). Forage evaluation in ruminant nutrition. Wallingford: $\mathrm{CAB}$ International, 2000. p.233-258.

KRISHNAMOORTHY, U.; MUSCATO, T.V.; SNIFFEN, C.J. et al. Nitrogen fractions in selected feedstuffs. Journal of Dairy Science, v.65, p.217-225, 1982.

McQUEEN, R.E.; NICHOLSON, J.W.G. Modification of the neutraldetergent fiber procedure for cereals and vegetables by using alpha-amylase. Journal of AOAC International, v.62, p.676-680, 1979.

MERTENS, D.R. Gravimetric determination of amylase treated neutral detergent fiber in feeds with refluxing in beaker or crucibles: collaborative study. Journal of AOAC International, v.85, p.1217-1240, 2002.

NOCEK, J.E. In situ and other methods to estimate ruminal protein and energy digestibility: a review. Journal of Dairy Science, v.71, p.2051-2069, 1988.

RUSSELL, J.B. Rumen microbiology and its role in ruminant nutrition. Ithaca: James B. Russell, 2002. 119p.

SAMPAIO, C.B.; DETMANN, E.; VALENTE, T.N.P. et al. Evaluation of fecal recovering and long term bias of internal and external markers in a digestion assay with cattle. Revista Brasileira de Zootecnia, v.40, p.174-182, 2011.
UNDERSANDER, D.; MERTENS, D.R.; THIEX, N. Forage analyses procedures. Omaha: National Forage Testing Association, 1993. 139p.

VALENTE, T.N.P.; DETMANN, E.; VALADARES FILHO, S.C. et al. Avaliação dos teores de fibra em detergente neutro em forragens, concentrados e fezes bovinas moídas em diferentes tamanhos e em sacos de diferentes tecidos. Revista Brasileira de Zootecnia, v.40, p.1148-1154, 2011a.

VALENTE, T.N.P.; DETMANN, E.; VALADARES FILHO, S.C. et al. In situ estimation of indigestible compounds contents in cattle feed and feces using bags made from different textiles. Revista Brasileira de Zootecnia, v.40, p.666-675, 2011b.

Van SOEST, P. J. The use of detergents in the analyses of fibrous feeds: II. A rapid method for determination of fiber and lignin. Journal of the Association of Official Agricultural Chemists, v.46, p.829, 1963.

Van SOEST, P.J. Development of a comprehensive system of feed analyses and its application to forages. Journal of Animal Science, v.26, p.119-128, 1967.

Van SOEST, P.J. Nutritional ecology of the ruminant. 2.ed. Ithaca: Cornell University Press, 1994. 476p.

Van SOEST, P.J.; ROBERTSON, J.B. Analysis of forage and fibrous foods. Ithaca: Cornell University, 1985. 202p.

Van SOEST, P.J.; ROBERTSON, J.B.; LEWIS, B.A.S. Methods for dietary fiber, neutral detergent fiber, and non-starch polysaccharides in relation to animal nutrition. Journal of Dairy Science, v.74, p.3583-3597, 1991.

VANZANT, E.S.; COCHRAN, C.; TITGEMEYER, E.C. Standardization of in situ techniques for ruminant feedstuff evaluation. Journal of Animal Science, v.76, p.2717-2729, 1998. 